\title{
Ultra high performance liquid chromatography tandem mass spectrometry for rapid analysis of trace organic contaminants in water
}

\author{
Tarun Anumol' ${ }^{1}$, Sylvain Merel ${ }^{1}$, Bradley O Clarke ${ }^{1,2}$ and Shane A Snyder ${ }^{1 *}$
}

\begin{abstract}
Background: The widespread utilization of organic compounds in modern society and their dispersion through wastewater have resulted in extensive contamination of source and drinking waters. The vast majority of these compounds are not regulated in wastewater outfalls or in drinking water while trace amounts of certain compounds can impact aquatic wildlife. Hence it is prudent to monitor these contaminants in water sources until sufficient toxicological data relevant to humans becomes available. A method was developed for the analysis of 36 trace organic contaminants (TOrCs) including pharmaceuticals, pesticides, steroid hormones (androgens, progestins, and glucocorticoids), personal care products and polyfluorinated compounds (PFCs) using a single solid phase extraction (SPE) technique with ultra-high performance liquid chromatography coupled to tandem mass spectrometry (UHPLC-MS/MS). The method was applied to a variety of water matrices to demonstrate method performance and reliability.

Results: UHPLC-MS/MS in both positive and negative electrospray ionization (ESI) modes was employed to achieve optimum sensitivity while reducing sample analysis time ( $<20 \mathrm{~min})$ compared with previously published methods. The detection limits for most compounds was lower than 1.0 picogram on the column while reporting limits in water ranged from 0.1 to $15 \mathrm{ng} / \mathrm{L}$ based on the extraction of a $1 \mathrm{~L}$ sample and concentration to $1 \mathrm{~mL}$. Recoveries in ultrapure water for most compounds were between 90-110\%, while recoveries in surface water and wastewater were in the range of $39-121 \%$ and $38-141 \%$ respectively. The analytical method was successfully applied to analyze samples across several different water matrices including wastewater, groundwater, surface water and drinking water at different stages of the treatment. Among several compounds detected in wastewater, sucralose and TCPP showed the highest concentrations.
\end{abstract}

Conclusion: The proposed method is sensitive, rapid and robust; hence it can be used to analyze a large variety of trace organic compounds in different water matrixes.

Keywords: Trace organic contaminant, Pharmaceutical, Personal-care product, Glucocorticoid, PFC, Solid-phase extraction, Ultra-high performance liquid chromatography, Tandem mass spectrometry, Water quality

\section{Background}

The environmental occurrence of pharmaceuticals, steroid hormones, pesticides and personal-care products, collectively termed as trace organic contaminants (TOrCs) or contaminants of emerging concern (CECs), has been consistently reported for over a decade [1-4]. The recalcitrance

\footnotetext{
* Correspondence: snyders2@email.arizona.edu

'Department of Chemical \& Environmental Engineering, University of Arizona, 1133 E James E Rogers Way, Harshbarger 108, Tucson, AZ 85721-0011, USA

Full list of author information is available at the end of the article
}

of certain TOrCs and their ability to pass through conventional drinking water treatment trains has necessitated frequent monitoring of these chemicals [5-7]. While the effects of many TOrCs on public health remains largely unknown, studies have shown that some of these contaminants can have drastic effects on aquatic organisms at concentrations present in wastewater [8,9]. In addition, other studies have demonstrated that a combination of TOrCs can have synergistic effects on some organisms $[9,10]$.

Numerous studies have focused on the analysis of estrogens, both natural and synthetic [11-13], but relatively less

\section{(Chemistry Central}


literature is available on the occurrence and analysis of other endocrine disruptors (glucocorticoids, progestins and androgens) in aquatic environments. Glucocorticoid receptor-active compounds (GRs) are known to control inflammation and infections and hence both natural and synthetic GRs have been used to prevent swelling, asthma and other diseases in humans [14]. This increased use combined with the fact that most GRs are poorly adsorbed in the human body and quickly excreted has led to their recent detection in wastewater and surface waters worldwide [14-16]. In this work we expanded the list of steroids typically included for analysis to include an androgen (testosterone), progestins (norethisterone and norgestrel) along with several GRs.

Polyfluorinated compounds (PFCs) are a relatively new sub-class of compounds within the TOrC classification. These compounds are synthetically produced and have a wide-range of applications, including in non-stick cookware, stain-resistant carpets, and surfactants among other things [17]. This frequent usage along with their inherent biological and chemical stability make PFCs persistent in the environment and frequently detected in water [17,18], biosolids [19] and biological matrices [20]. Consequently, the two most commonly used PFCs (PFOA and PFOS) are on the USEPA's Contaminant Candidate List 3 [21]. In addition, bioaccumulation properties, potential carcinogenicity and recent reports on toxic effects to animals [22,23] have led to the voluntary reduction in usage of PFOA and the banning of PFOS in Europe [24]. However, these two compounds are progressively being replaced by shorter chain $(C<7)$ PFC's [25], of which far less is known with regards to toxicity and occurrence data. Accordingly, this study set out to include six PFCs with C4-C16 carbon chain length.

Over 82,000 chemicals are registered for industrial use in the US and the number is rapidly increasing [26]. Monitoring each chemical is not feasible; hence the significance of selecting 'indicator' compounds that encompass the various classes of TOrCs is critical. Recent studies have sought to identify indicator TOrCs based on their occurrence and attenuation in the environment [27]. This study selected 36 disparate compounds across seven classes of TOrCs for analysis using a single extraction method and short analysis time.

As the number of environmental contaminants monitored continues to increase rapidly, the need for reliable analytical methods offering selectivity, sensitivity and reproducibility also has increased. Over the years, numerous methods relying on a variety of instruments were developed to measure TOrCs. For instance, gas chromatography has been used to analyze volatile compounds and pesticides as well as some polar compounds and steroids using derivatization agents [28,29]. However, these techniques are time-consuming, labor intensive and limited to the analysis of compounds that are volatile and not thermally-labile.

Liquid chromatography methods have proved more effective in analyzing TOrCs. While methods using UV $[30,31]$ and fluorescence $[32,33]$ detectors have been proposed, methods using both single quadrupole $[34,35]$ and triple quadrupole [36,37] mass spectrometers have been most common. However, the vast majority of these methods consider only specific classes of pharmaceuticals $[38,39]$ or compounds with similar polarities and/ or use numerous extraction methods that are timeconsuming and labor-intensive. Only few methods use a single extraction procedure while still analyzing a wide variety of these compounds $[29,40,41]$. With the introduction of ultra-high performance liquid chromatography (UHPLC), it is now possible to operate at extremely high pressures with much smaller particle sizes which allows for rapid separation of analytes while also improving resolution and sensitivity.

This study aims to provide a simple, rapid, sensitive and robust method for the targeted analysis of 36 compounds (Table 1) representative of several TOrC classes usually considered by water utilities and regulatory agencies. The method includes several different classes of TOrCs including less studied substances like GRs and PFCs. The application of UHPLC allows for a significant reduction in sample runtime while providing good analytical separation compared to previously published methods and also providing very low ng/L detection limits in water. The proposed method includes the addition of 19 stable isotopically labeled compounds to increase accuracy and precision. This method was successfully applied to groundwater, surface water and wastewater matrices.

\section{Experimental}

\section{Chemicals and reagents}

All standards and reagents used during the study were of the highest purity commercially available $(\geq 97 \%$ for all compounds). All native standards were procured from Sigma-Aldrich (St. Louis, MO) except perfluorohexadecanoic acid (PFHxDA) from Matrix Scientific (Columbia, $\mathrm{SC}$ ); meprobamate from Cerilliant (Round Rock, TX); and triclosan from Alfa Aesar (Ward Hill, MA). Labeled standards were purchased from Cambridge Isotope Laboratories (Andover, MA) except ${ }^{13} \mathrm{C}_{4}$-PFOA, ${ }^{13} \mathrm{C}_{4}$-PFOS, ${ }^{13} \mathrm{C}_{2}$-PFHxA, ${ }^{13} \mathrm{C}_{4}$-PFBA from Wellington Laboratories (Ontario, Canada); primidone- $\mathrm{d}_{5}$ and ${ }^{13} \mathrm{C}_{6}$-diclofenac from Toronto Research Chemicals (Ontario, Canada); and gemfibrozil- $\mathrm{d}_{6}$ from $\mathrm{C} / \mathrm{D} / \mathrm{N}$ Isotopes (Quebec, Canada). A working stock of all native standards was prepared at $5 \mathrm{mg} / \mathrm{L}$ in pure methanol and diluted as required to obtain the desired concentration of calibration standards. A mix of all isotopically labeled surrogates at $1 \mathrm{mg} / \mathrm{L}$ in pure methanol was also prepared and used to spike all samples 
Table 1 Target compounds with use and class

\begin{tabular}{|c|c|c|}
\hline Compound & Use & Class \\
\hline Atrazine & Pesticide & Pesticide \\
\hline Benzophenone & UV Blocker & $\begin{array}{l}\text { Personal Care } \\
\text { Product }\end{array}$ \\
\hline Bisphenol A & Plasticizer & $\begin{array}{l}\text { Industrial } \\
\text { compound }\end{array}$ \\
\hline Caffeine & Stimulant & $\begin{array}{l}\text { Personal Care } \\
\text { Product }\end{array}$ \\
\hline Carbamazepine & Anticonvulsant & Pharmaceutical \\
\hline $\begin{array}{l}\mathrm{N}, \mathrm{N} \text {-Diethyl-meta-toluamide } \\
\text { (DEET) }\end{array}$ & Insect Repellant & $\begin{array}{l}\text { Personal Care } \\
\text { Product }\end{array}$ \\
\hline Dexamethasone & $\begin{array}{c}\text { Anti- } \\
\text { Inflammatory }\end{array}$ & Glucocorticoid \\
\hline Diclofenac & Anti-arthritic & Pharmaceutical \\
\hline Diltiazem & Antiarrhythmic & Pharmaceutical \\
\hline Diphenhydramine & Anti-histamine & Pharmaceutical \\
\hline Fluoxetine & Anti-Depressant & Pharmaceutical \\
\hline Gemfibrozil & Anti-Cholesterol & Pharmaceutical \\
\hline Hydrocortisone (Cortisol) & $\begin{array}{c}\text { Anti- } \\
\text { inflammatory }\end{array}$ & Glucocorticoid \\
\hline Ibuprofen & Analgesic & Pharmaceutical \\
\hline Meprobamate & Anti-anxiety & Pharmaceutical \\
\hline Naproxen & Analgesic & Pharmaceutical \\
\hline Norethisterone & Contraceptive & Progestin \\
\hline Norgestrel & Contraceptive & Progestin \\
\hline $\begin{array}{l}\text { Perfluoro butanoic } \\
\text { acid (PFBA) }\end{array}$ & Fluorosurfactant & $\begin{array}{l}\text { Polyfluorinated } \\
\text { Compound }\end{array}$ \\
\hline $\begin{array}{l}\text { Perfluoro butane } \\
\text { sulfonate (PFBS) }\end{array}$ & Fluorosurfactant & $\begin{array}{l}\text { Polyfluorinated } \\
\text { Compound }\end{array}$ \\
\hline $\begin{array}{l}\text { Perfluoro decanoic } \\
\text { acid (PFDA) }\end{array}$ & Fluorosurfactant & $\begin{array}{l}\text { Polyfluorinated } \\
\text { Compound }\end{array}$ \\
\hline $\begin{array}{c}\text { Perfluoro hexadecanoic } \\
\text { acid (PFHxDA) }\end{array}$ & Fluorosurfactant & $\begin{array}{l}\text { Polyfluorinated } \\
\text { Compound }\end{array}$ \\
\hline $\begin{array}{l}\text { Perfluoro octanoic } \\
\text { acid (PFOA) }\end{array}$ & Fluorosurfactant & $\begin{array}{l}\text { Polyfluorinated } \\
\text { Compound }\end{array}$ \\
\hline $\begin{array}{l}\text { Perfluoro octane } \\
\text { sulfonate (PFOS) }\end{array}$ & Fluorosurfactant & $\begin{array}{l}\text { Polyfluorinated } \\
\text { Compound }\end{array}$ \\
\hline Prednisone & $\begin{array}{c}\text { Anti- } \\
\text { inflammatory }\end{array}$ & Glucocorticoid \\
\hline Primidone & Anticonvulsant & Pharmaceutical \\
\hline Simazine & Herbicide & Pesticide \\
\hline Sucralose & $\begin{array}{l}\text { Artificial } \\
\text { Sweetener }\end{array}$ & $\begin{array}{l}\text { Personal Care } \\
\quad \text { Product }\end{array}$ \\
\hline Sulfamethoxazole & Antibiotic & Pharmaceutical \\
\hline $\begin{array}{l}\text { Tris (2-chloroethyl) } \\
\text { phosphate (TCEP) }\end{array}$ & Flame retardant & $\begin{array}{l}\text { Industrial } \\
\text { compound }\end{array}$ \\
\hline $\begin{array}{l}\text { Tris (2-chloropropyl) } \\
\text { phosphate (TCPP) }\end{array}$ & Flame retardant & $\begin{array}{l}\text { Industrial } \\
\text { compound }\end{array}$ \\
\hline Testosterone & Androgen & Androgen \\
\hline Triamcinolone & $\begin{array}{l}\text { Synthetic } \\
\text { corticosteroid }\end{array}$ & Glucocorticoid \\
\hline
\end{tabular}

Table 1 Target compounds with use and class (Continued)

\begin{tabular}{|c|c|c|}
\hline Triclocarban & Antibiotic & $\begin{array}{c}\text { Personal Care } \\
\text { Product }\end{array}$ \\
\hline Triclosan & Anti-microbial & $\begin{array}{c}\text { Personal Care } \\
\text { Product }\end{array}$ \\
\hline Trimethoprim & Antibiotic & Pharmaceutical \\
\hline
\end{tabular}

before extraction. These two solutions were stored in the dark at $-20^{\circ} \mathrm{C}$ and new working stocks were prepared every two months. Both stocks were injected routinely on the mass spectrometer and signal response was monitored for each compound to determine if there was any degradation with time.

All solvents were of the highest purity available and suitable for LC-MS analysis. Methanol (HPLC grade), MTBE (HPLC grade), formic acid (LC/MS grade) and ammonium hydroxide (ACS grade) were obtained from Fisher Scientific (Pittsburgh, PA), while acetonitrile and ultrapure water (both HPLC grade) were obtained from Burdick and Jackson (Muskegon, MI).

\section{Sample collection and preservation}

Grab samples were collected from four full-scale water treatment plants across the United States. In addition, multiple samples from two surface waters and a groundwater from Tucson, Arizona were analyzed. Samples (1 $\mathrm{L}$ each) were collected in silanized amber glass bottles containing $50 \mathrm{mg}$ of ascorbic acid to quench residual chlorine and $1 \mathrm{~g}$ of sodium azide to prevent microbial activity. Samples were sent to the laboratory in coolers containing icepacks and filtered through a $0.7 \mu \mathrm{m}$ glass filter (Whatman, England) immediately upon arrival. Then, samples were stored in darkness at $4^{\circ} \mathrm{C}$ and extracted within 14 days. Sample preservation techniques were comparable to those previously published by Vanderford et al. [42].

\section{Solid-phase extraction}

All samples were spiked with 19 isotopically labeled surrogate standards at concentrations varying from 50 to $200 \mathrm{ng} / \mathrm{L}$ depending on analytical sensitivity and matrix type. Samples were then extracted using an AutoTrace 280 automated SPE system from Dionex (Sunnyvale, CA) using $200 \mathrm{mg}$ hydrophilic-lipophilic balance (HLB) cartridges (Waters Corporation; Millford, MA). Cartridges were first preconditioned with $5 \mathrm{ml}$ of MTBE, followed by $5 \mathrm{ml}$ of methanol and $5 \mathrm{ml}$ of ultrapure water. Samples were then loaded at $15 \mathrm{ml} / \mathrm{min}$ onto the cartridges which were subsequently rinsed with ultrapure water and dried under nitrogen flow for $30 \mathrm{~min}$. While $1 \mathrm{~L}$ samples were collected, different volumes of sample were extracted 
based on the matrix. The analytes were then eluted with $5 \mathrm{ml}$ of methanol followed by $5 \mathrm{ml}$ of $10 / 90(\mathrm{v} / \mathrm{v})$ methanol/MTBE solution. The eluent was evaporated to less than $500 \mu \mathrm{l}$ using gentle nitrogen flow and the volume was adjusted to $1 \mathrm{ml}$ by addition of methanol. Final extracts were transferred into 2-mL vials and stored in darkness at $4^{\circ} \mathrm{C}$ until UHPLC-MS/MS analysis.

\section{Liquid chromatography}

Liquid chromatography was performed on $3 \mu \mathrm{L}$ of sample extract using an Agilent 1290 binary pump (Palo Alto, CA) with metal solvent fittings for all analyses. The Agilent RRHD ZORBAX Eclipse Plus reverse phase C18 column $(2.1 \times 50 \mathrm{~mm})$ with a packing size of $1.8 \mu \mathrm{m}$ was used to separate analytes in both the negative and positive electrospray ionization (ESI) modes. The column was maintained at a temperature of $30^{\circ} \mathrm{C}$ for the entire run in both modes.

The mobile phase for ESI positive used two solvents comprising (A) ultrapure water with $0.1 \%$ formic acid and (B) acetonitrile with $0.1 \%$ formic acid. With a constant flowrate of $400 \mu \mathrm{l} / \mathrm{min}$, solvent B was held at $5 \%$ for $1.5 \mathrm{~min}$. Solvent B then linearly increased to $20 \%$ at $3 \mathrm{~min}, 45 \%$ at $4 \mathrm{~min}, 65 \%$ at $6.1,100 \%$ at $7 \mathrm{~min}$ and held till $7.45 \mathrm{~min}$. A post-run of $1.45 \mathrm{~min}$ was added to allow the column to re-equilibrate before the next analysis. This resulted in a total run-time of $9.90 \mathrm{~min}$ for analysis of 23 analytes (Additional file 1: Table S1 and Figure 1).

The mobile phase for ESI negative used a dual eluent system comprising (A) $5 \mathrm{mM}$ ammonium acetate in ultrapure water and (B) 10/90 (v/v) water/acetonitrile with $5 \mathrm{mM}$ ammonium acetate. With a constant flowrate of $400 \mu \mathrm{l} / \mathrm{min}$, solvent B was linearly increased from $20 \%$ to $96 \%$ at $4.5 \mathrm{~min}$ and $100 \%$ at $5 \mathrm{~min}$. Solvent B was held at $100 \%$ for a further $1.3 \mathrm{~min}$ then a post-run of $1.5 \mathrm{~min}$ at $20 \% \mathrm{~B}$ was added to allow the column to re-equilibrate before the next analysis. This resulted in a total run-time of $7.8 \mathrm{~min}$ for the analysis of 13 analytes (Additional file 1: Table S1 and Figure 2). Sample chromatograms for positive and negative ionization modes at $100 \mathrm{ng} / \mathrm{mL}$ are shown in Figures 1 and 2.

\section{Mass spectrometry}

Mass spectrometry was performed using an Agilent 6460 triple quadrupole mass spectrometer. Optimization was done in two steps: compound-specific and sourcedependent. Initially, each compound was prepared from a neat standard at a concentration of $1 \mu \mathrm{g} / \mathrm{ml}$ in pure methanol and injected into the mass spectrometer at a flowrate of $500 \mu \mathrm{l} / \mathrm{min}$. The first quadrupole was set to scan mode and the most intense precursor ion was selected. This was done both in positive and negative electrospray modes to select the most appropriate ion source for each compound. After the best ion source was chosen, the fragmentor voltage was optimized for each compound in scan mode. After this, the mass spectrometer was run in product ion scan (PI Scan) mode to determine the most abundant product. For this, collision energy (CE) of 20 volts was selected and then adjusted in steps of 10 to find the most abundant products. For most compounds, two transitions; a quantifier (the most abundant product) and a qualifier (the second most abundant product) were selected. Then, the mass spectrometer was set to multiple reaction monitoring (MRM) mode and the CE for each product ion was optimized. This was followed by optimization of the cell accelerator voltage (CAV); however, it was noticed that there was a possibility of cross talk between some compounds especially at low CAVs so this value was only optimized between two and seven. The analyte transitions, optimized parameters and retention times are given in Additional file 1: Table S1.

Once all the compound-specific parameters were optimized, source parameters like gas temperature, flow rate, nozzle voltage, nebulizer and capillary voltage were tuned. While, it was not possible to have optimum source parameters to suit all the compounds, best fit values were used in choosing these parameters. The source-dependent parameters for both positive and negative electrospray ionization modes are detailed in Table 2. Analysis in both ESI modes was performed using a dynamic MRM method with a delta retention time of $0.6 \mathrm{~min}$ for ESI positive mode and 0.8 min for ESI negative mode.

Data analysis and interpretation was carried out with the Agilent MassHunter software (version Rev. B.05.00). Along with monitoring the labeled isotope recoveries and the retention time, the ratio of the two transitions was also noted, which increased the accuracy of detection and reduced the possibility of false positives of the method.

\section{Determination of $L O D, L O Q$ and $M R L$}

The instrumental limit of detection (LOD) and limit of quantification (LOQ) were determined for each compound by injecting standards at $0.02,0.05,0.1,0.5,1$, 2.5, 5, 10 and $25 \mu \mathrm{g} / \mathrm{L}$ on the UHPLC-MS/MS system. The LOD and LOQ were defined as the concentration for which the signal to noise ratio (SNR) was greater than 3 and 10 respectively. The LOD and LOQ of all target analytes are shown in Table 3 .

The method reporting limit (MRL) was determined by extracting nine samples (1 L each) of ultrapure water fortified with the target analytes at 2-3 times the LOQ (calculated from above) and spiked with isotopicallylabeled surrogates. After extraction and analysis, the MRL was calculated by multiplying the standard deviation with the student's t-test value for n-1 degrees of freedom at $99 \%$ confidence levels. The results are shown 

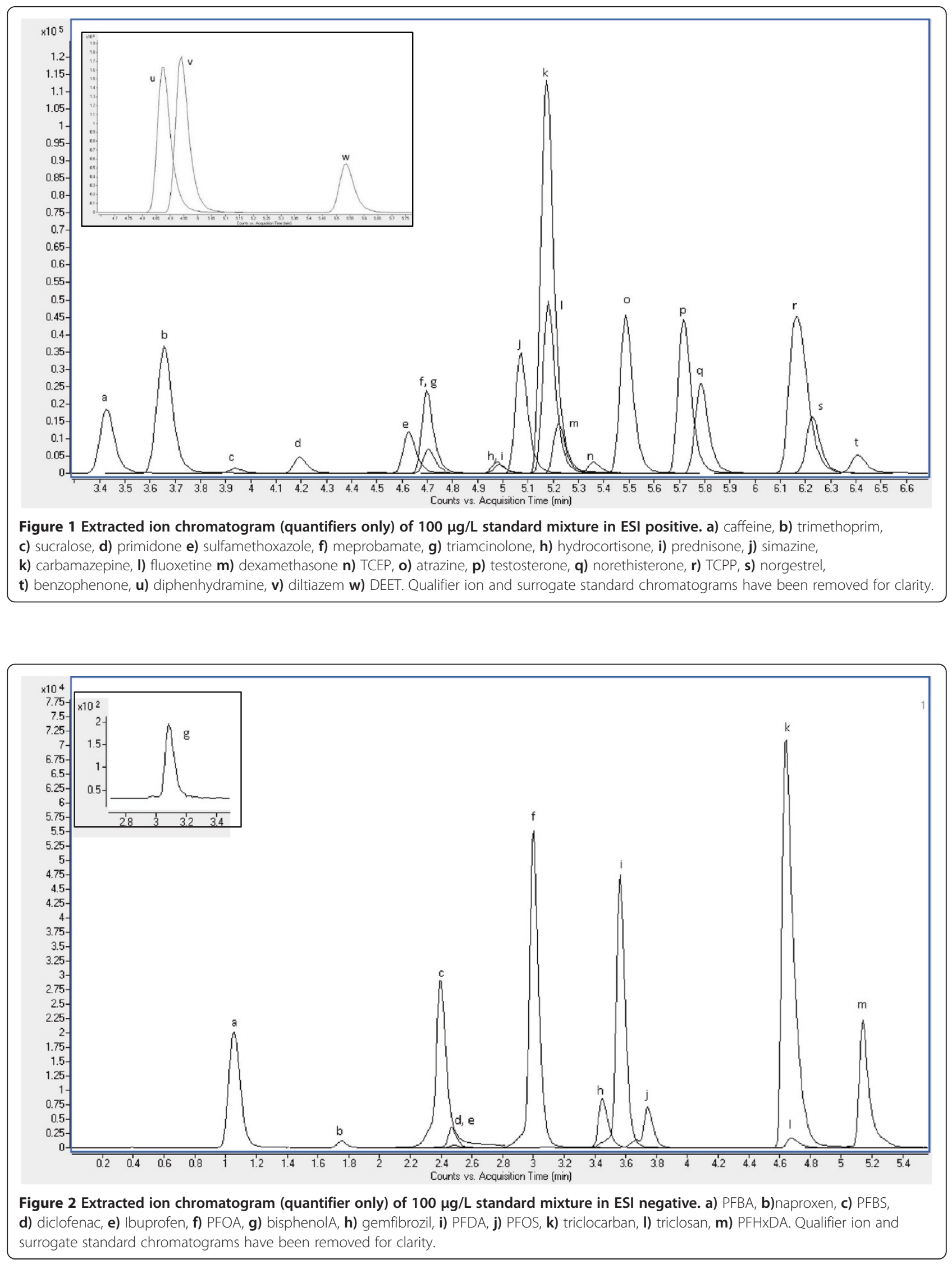
Table 2 Mass spectrometer source-dependent parameters

\begin{tabular}{lcc}
\hline Parameter & ESI Positive & ESI Negative \\
\hline Gas Temperature $\left({ }^{\circ} \mathrm{C}\right)$ & 275 & 225 \\
Gas Flowrate $(\mathrm{L} / \mathrm{min})$ & 11 & 10 \\
Nebulizer (psi) & 45 & 45 \\
Sheath Gas Temperature $\left({ }^{\circ} \mathrm{C}\right)$ & 375 & 350 \\
Sheath Gas Flowrate $(\mathrm{L} / \mathrm{min})$ & 11 & 11 \\
Capillary $(\mathrm{V})$ & 4000 & 3600 \\
Nozzle Voltage $(\mathrm{V})$ & 0 & 1500 \\
Delta EMV $(\mathrm{V})$ & 400 & 400 \\
\hline
\end{tabular}

in Table 3. The method reporting limits determined were similar and in many cases lower than previously published literature $[29,43]$.

\section{Results and discussion}

\section{Chromatography}

Optimization of chromatographic conditions was achieved by performing experiments with various mixtures of organic solvents and $\mathrm{pH}$ modifying buffers. The best mobile phase was chosen based on peak shape, peak resolution and sensitivity achieved for all compounds. Three different UHPLC reverse phase columns were also tested and the column providing the highest sensitivity for most target analytes was chosen. Details of the three columns tested are provided in Additional file 2: Table S2. Once the column and the mobile phase were selected, the gradients in both modes were optimized to achieve best separation of all target analytes while maintaining a sufficient scan speed and peak width to preserve peak shape allowing accurate integration. In addition, different injection volumes $(1,3,5$ and $10 \mu \mathrm{l})$ were also tested and $3 \mu \mathrm{l}$ was used for all analysis as this gave the highest sensitivity without alteration of peak shape.

\section{Analyte ionization and data analysis}

All but one compound were ionized by protonation $\left[(\mathrm{M}+\mathrm{H})^{+}\right]$of the uncharged molecule in the ESI positive mode. Sucralose was analyzed with the addition of a sodium adduct $\left[(\mathrm{M}+\mathrm{Na})^{+}\right]$as the $\left[(\mathrm{M}+\mathrm{H})^{+}\right]$ion was essentially absent during optimization of the compound. In the ESI negative mode, all the compounds analyzed were a result of deprotonation $\left[(\mathrm{M}-\mathrm{H})^{-}\right]$of the original neutral molecule.

The quantification of TOrCs in all samples was achieved using a calibration curve with at least nine points and an $\mathrm{R}^{2}$ no lower than 0.990 and typically above 0.995 . All concentrations above the calibration range were diluted and re-analyzed. In a few instances, it was not possible to determine the exact concentration of an analyte due to loss of isotope signal because of dilution. In this case, concentration were reported as ' $>$ ' the highest calibration
Table 3 LOD, LOQ and MRL of target analytes

\begin{tabular}{|c|c|c|c|}
\hline Compound & LOD $(\mu \mathrm{g} / \mathrm{L})$ & LOQ ( $\mu \mathrm{g} / \mathrm{L})$ & Practical MRL (ng/L) \\
\hline \multicolumn{4}{|c|}{ ESI positive } \\
\hline Caffeine & 0.5 & 1 & 2.5 \\
\hline Trimethoprim & 0.05 & 0.1 & 0.1 \\
\hline Sucralose & 1 & 5 & 10 \\
\hline Triamcinolone & 1 & 2.5 & 5 \\
\hline Primidone & 1 & 2.5 & 2.5 \\
\hline Sulfamethoxazole & 0.02 & .1 & .5 \\
\hline Meprobamate & 0.1 & 1 & 2.5 \\
\hline Diphenylhydramine & 0.02 & 0.1 & 1 \\
\hline Diltiazem & 0.02 & 0.1 & 0.5 \\
\hline Hydracortisone & 0.5 & 1 & 2.5 \\
\hline Prednisone & 10 & 15 & 20 \\
\hline Simazine & 0.1 & 0.5 & 1 \\
\hline Fluoxetine & 0.02 & 0.05 & 0.5 \\
\hline Carbamazepine & 0.05 & 0.1 & 0.25 \\
\hline Dexamethasone & 0.05 & 0.5 & 1 \\
\hline TCEP & 0.5 & 1 & 2.5 \\
\hline Atrazine & 0.1 & 0.5 & 0.5 \\
\hline DEET & 0.05 & 0.1 & $2.5^{*}$ \\
\hline Testosterone & 0.5 & 1 & 1 \\
\hline Norethistrone & 0.1 & 0.5 & 1 \\
\hline TCPP & 0.05 & 1 & 2.5 \\
\hline Norgestrel & 0.5 & 1 & 2.5 \\
\hline Benzophenone & 0.02 & 0.5 & 1 \\
\hline \multicolumn{4}{|c|}{ ESI negative } \\
\hline PFOA & 0.02 & 0.5 & 1 \\
\hline PFDA & 0.02 & 0.5 & 2.5 \\
\hline Gemfibrozil & 0.05 & 0.5 & 1 \\
\hline PFOS & 0.02 & 0.05 & 0.1 \\
\hline Triclocarban & 0.1 & 0.5 & 1 \\
\hline Triclosan & 0.5 & 2.5 & 5 \\
\hline PFHXDA & 0.02 & 0.1 & 0.5 \\
\hline PFBS & 0.02 & 0.05 & 0.5 \\
\hline PFBA & 0.02 & 0.02 & NA \\
\hline Ibuprofen & 5 & 10 & 15 \\
\hline Bisphenol A & 1 & 5 & 15 \\
\hline Naproxen & 0.1 & 1 & 2.5 \\
\hline Diclofenac & 0.1 & 0.5 & 2.5 \\
\hline
\end{tabular}

NA Not analyzed; * Adjusted for blank.

point. While the MRL for all TOrCs was reported in ultrapure water, this value could be impaired in other water matrices containing natural organic matter that interfere with the ionization of the analytes. To account for this, a separate MRL was determined for each sample. Initially, the lowest calibration point was chosen at or 
slightly above the MRL determined in ultrapure water. Using the Mass Hunter software, the expected concentrations of the calibration curve were recalculated based on the calibration equation and $R^{2}$ using a linear regression with $1 / \mathrm{X}$ weighting. After comparing the calculated concentrations of all the calibration points with expected concentrations, the lowest calibration point with accuracy between $70-130 \%$ was chosen for each analyte. This value was then divided by the isotope recovery obtained for all analytes in each sample to obtain the "true" MRL in that particular sample matrix.

\section{Matrix spike and recoveries}

Recoveries for the target analytes after extraction were determined using six replicates in three different water matrices shown in Table 4. Matrix spike levels were chosen as $100 \mathrm{ng} / \mathrm{L}$ in ultrapure water and $200 \mathrm{ng} / \mathrm{L}$ in surface water and wastewater samples. The spike recoveries were calculated by comparing this known spiking concentration with the concentration determined in unspiked samples by internal standard calibration. For ultrapure water, more than $70 \%$ of the compounds had a recovery between $90-110 \%$. Only two compounds (diltiazem and PFHxDA) had a recovery of $<70 \%$. The recoveries in the surface water varied from $39-121 \%$ while wastewater recoveries ranged from $38-141 \%$. While these ranges seem large, it is important to note that isotopically-labeled surrogate standards were not available for every compound. All compounds with a surrogate standard had corrected recoveries between $73-121 \%$ with the exception of diclofenac $(64 \%)$ in the wastewater spike. In fact, almost all these compounds had recoveries of $85-115 \%$ further validating the use of isotope dilution to correct for matrix suppression and losses during SPE. The recovery of norgestrel and norethisterone were below $60 \%$ in the surface water and wastewater spike samples. Previous studies have shown that these two compounds have poor stability on storage greater than three days and this may have led to loss of analyte in the sample [44]. While every effort was made to extract the samples as soon as possible, extraction times varied between 3-14 days during this study. Spike recoveries for hydrocortisone were found to be $50 \%$ and $38 \%$ in surface water and wastewater respectively. Similar recoveries $(\sim 60 \%)$ have been seen in a previous study in wastewater [16]. To obtain better recoveries for all compounds, the use of multiple extraction procedures, and considering compound specific properties would be necessary. It was decided to proceed with this single extraction method that provided good recoveries for the majority of the compounds while allowing for significant savings in time and labor. The precision of the entire method was good as the relative standard deviation (RSD) of the replicates for almost all compounds was less than $10 \%$ in both ultrapure and surface water. While larger RSDs were observed for wastewater samples, compounds with surrogate standards were still extremely reproducible. Overall, the use of surrogate standards to correct for loss of target analytes during the extraction and analysis stages proved reliable.

\section{Matrix suppression}

The degree of matrix suppression encountered was analyzed by comparing the instrument response (area count) of the 19 isotopically-labeled standards in the matrix spikes and samples with six instrument blanks spiked at the same concentration. The isotope recovery data in each matrix is presented in Table 5. Fluoxetine $\mathrm{d}_{5}$, PFBA ${ }^{13} \mathrm{C}_{4}$ and diclofenac ${ }^{13} \mathrm{C}_{6}$ were the only isotopically-labeled compounds to have $<60 \%$ recovery in ultrapure water. The degree of suppression for most compounds increased in the wastewater matrix $(250 \mathrm{~mL})$ compared to the surface water $(1000 \mathrm{~mL})$ and ultrapure water $(1000 \mathrm{~mL})$ spikes even though less volume of the sample was extracted. The RSD for all analytes was below $15 \%$ and in most cases below $5 \%$.

\section{Blank analysis}

As extremely low levels of analytes are quantified in this method, there was a possibility of contamination through various sources. Potential contamination may arise from presence of trace levels of native compound in the isotopically-labeled standards, presence of contamination in the instrument, and low-level contamination from various external sources. Initially pure methanol was injected in both ESI modes to detect the presence of any background contamination due to the solvent or instrument (Additional file 3: Figure S1 and Additional file 4: Figure S2). The target analytes were not found to be present with the exception of DEET. Next methanol blanks were fortified with the isotopically-labeled standards to determine if native compounds were introduced by the isotopes. No indication of target analyes was found in these blanks with the exception of DEET. The area counts of the DEET chromatograms present in the first two types of blanks was very similar indicating that the DEET detected was in the background and not introduced by the isotopicallylabeled standard (Additional file 5: Figure S3). The concentration of DEET in the blanks was estimated using the MRL study calibration curve and subsequently the MRL for DEET was increased five times to prevent reporting of false positives. Finally, a number $(n=6)$ of ultrapure water samples fortified with labeled isotopes were extracted by SPE and analyzed to ensure the absence of unlabeled compounds through the extraction procedure. Further, routine fortified ultrapure water blanks were analyzed along with the samples to check for any contamination. All blanks tested during the course of the study were below MRLs. 
Table 4 Matrix spike recoveries for all target analytes in three different waters

\begin{tabular}{|c|c|c|c|c|c|c|}
\hline \multirow[t]{2}{*}{ Compounds } & \multicolumn{2}{|c|}{ Ultrapure water } & \multicolumn{2}{|c|}{ Surface water } & \multicolumn{2}{|c|}{ WW effluent } \\
\hline & Recovery (\%) & $\overline{\text { RSD (\%) }}$ & Recovery (\%) & $\overline{\text { RSD (\%) }}$ & Recovery (\%) & RSD (\%) \\
\hline \multicolumn{7}{|c|}{ ESI positive } \\
\hline Caffeine & 106 & 2.5 & 95 & 4.3 & 100 & 3.9 \\
\hline Trimethoprim & 98 & 2.1 & 102 & 0.9 & 114 & 3.2 \\
\hline Sucralose & 95 & 5.4 & 73 & 34.1 & NA & NA \\
\hline Primidone & 97 & 2.9 & 96 & 1.5 & 113 & 10.0 \\
\hline Triamcinolone & 101 & 4.7 & 48 & 2.3 & 106 & 4.3 \\
\hline Sulfamethoxazole & 105 & 3.3 & 98 & 1.7 & 99 & 2.1 \\
\hline Meprobamate & 97 & 5 & 74 & 1.5 & 99 & 8.4 \\
\hline Diphenylhydramine & 74 & 5.4 & 94 & 5.4 & 196 & 3.8 \\
\hline Diltiazem & 67 & 11.7 & NA & NA & NA & NA \\
\hline Hydracortisone & 84 & 3.7 & 50 & 7.3 & 38 & 11.3 \\
\hline Prednisone & 94 & 4.1 & 75 & 5.4 & 79 & 10.0 \\
\hline Simazine & 99 & 3 & 73 & 2.0 & 66 & 2.6 \\
\hline Carbamezapine & 101 & 2.1 & 117 & 1.3 & 98 & 25.5 \\
\hline Fluoxetine & 89 & 5.5 & 97 & 2.3 & 99 & 5.5 \\
\hline Dexamethasone & 91 & 2.7 & 86 & 2.2 & 88 & 3.4 \\
\hline TCEP & 108 & 3.1 & 71 & 4.3 & 119 & 8.1 \\
\hline Atrazine & 100 & 2.7 & 94 & 1.9 & 99 & 2.5 \\
\hline DEET & 101 & 2.7 & 96 & 1.6 & 98 & 5.5 \\
\hline Testosterone & 82 & 3.3 & 42 & 2.4 & 42 & 21.6 \\
\hline Norethistrone & 79 & 2.4 & 39 & 1.9 & 54 & 2.1 \\
\hline TCPP & 97 & 2.4 & 119 & 2.9 & 74 & 7.1 \\
\hline Norgestrel & 82 & 3.2 & 57 & 1.3 & 55 & 6.7 \\
\hline Benzophenone & 71 & 15.8 & 95 & 6.4 & 93 & 26.4 \\
\hline \multicolumn{7}{|c|}{ ESI negative } \\
\hline PFBA & 95 & 4.6 & NA & NA & NA & NA \\
\hline Naproxen & 95 & 3.5 & 89 & 1.4 & 80 & 6.0 \\
\hline PFBS & 78 & 7.1 & 111 & 8.0 & 87 & 3.6 \\
\hline Diclofenac & 103 & 5.4 & 96 & 6.0 & 64 & 22.0 \\
\hline Ibuprofen & 96 & 9.2 & 92 & 5.7 & 96 & 10.8 \\
\hline PFOA & 101 & 2.3 & 121 & 6.4 & 115 & 7.4 \\
\hline Bisphenol A & 91 & 15.5 & 97 & 11.6 & 87 & 10.8 \\
\hline Gemfibrozil & 104 & 3.7 & 93 & 2.7 & 111 & 10.0 \\
\hline PFDA & 97 & 3.6 & 73 & 15.3 & 65 & 13.4 \\
\hline PFOS & 107 & 2.9 & 94 & 9.0 & 89 & 9.8 \\
\hline Triclocarban & 105 & 2.8 & 97 & 1.5 & 107 & 5.0 \\
\hline Triclosan & 74 & 1.1 & 112 & 2.8 & 141 & 6.7 \\
\hline PFHxDA & 46 & 72.4 & 56 & 10.4 & 66 & 18.4 \\
\hline
\end{tabular}

NA Not Analyzed.

\section{Occurrence in water}

To demonstrate the applicability of this method, samples from three WWTPs, a drinking water treatment plant (DWTP), one ground water and two surface waters
(Colorado River and Sacramento River) from around the United States were analyzed. Samples from the three wastewater treatment plants were also analyzed at different treatment points to study treatment efficacy. A 
Table 5 Percent recovery of isotopically labeled standards in different water matrixes $(n=6)$

\begin{tabular}{|c|c|c|c|c|c|c|}
\hline \multirow[t]{2}{*}{ Compound } & \multicolumn{2}{|c|}{ Ultrapure water $(1000 \mathrm{ml})$} & \multicolumn{2}{|c|}{ Surface water (1000 ml) } & \multicolumn{2}{|c|}{ WWTP effluent (250 ml) } \\
\hline & Recovery (\%) & RSD (\%) & Recovery (\%) & RSD (\%) & Recovery (\%) & RSD (\%) \\
\hline Carbamezapine $d_{10}$ & 77 & 4.4 & 79 & 2.6 & 70 & 4.9 \\
\hline Caffeine ${ }^{13} C_{3}$ & 79 & 4.7 & 76 & 3.2 & 56 & 4.5 \\
\hline Trimethoprim $d_{3}$ & 67 & 4.2 & 66 & 3.1 & 41 & 6.4 \\
\hline Sucralose $d_{6}$ & 65 & 5.9 & 31 & 3.3 & 16 & 4.0 \\
\hline Primidone $d_{5}$ & 81 & 3.1 & 71 & 4.0 & 74 & 4.3 \\
\hline Sulfamethoxazole ${ }^{13} \mathrm{C}_{6}$ & 80 & 3.6 & 30 & 4.6 & 28 & 6.6 \\
\hline Atrazine $d_{5}$ & 70 & 3.1 & 59 & 4.1 & 64 & 3.9 \\
\hline Fluoxetine $d_{5}$ & 40 & 8.3 & 35 & 6.8 & 40 & 10.7 \\
\hline DEET $d_{6}$ & 60 & 9.2 & 70 & 6.8 & 75 & 10.8 \\
\hline PFBA ${ }^{13} C_{4}$ & 15 & 2.1 & 13 & 3.4 & 10 & 5.2 \\
\hline Naproxen ${ }^{13} \mathrm{C}_{1} \mathrm{~d}_{3}$ & 87 & 4.5 & 94 & 3.6 & 75 & 6.2 \\
\hline Diclofenac ${ }^{13} \mathrm{C}_{6}$ & 48 & 1.5 & 30 & 7.5 & 31 & 14.5 \\
\hline Ibuprofen $d_{3}$ & 86 & 6.5 & 103 & 4.7 & 90 & 6.5 \\
\hline PFOA ${ }^{13} C_{4}$ & 90 & 3.1 & 115 & 14.3 & 104 & 0.3 \\
\hline Bisphenol $\mathrm{A}{ }^{13} \mathrm{C}_{12}$ & 92 & 6.9 & 70 & 7.8 & 83 & 11.0 \\
\hline Gemfibrozil $d_{6}$ & 86 & 3.1 & 94 & 4.6 & 117 & 4.9 \\
\hline PFOS ${ }^{13} C_{4}$ & 83 & 4.2 & 78 & 7.7 & 81 & 5.7 \\
\hline Triclocarban ${ }^{13} \mathrm{C}_{6}$ & 61 & 7.5 & 63 & 3.3 & 54 & 5.7 \\
\hline Triclosan $d_{3}$ & 122 & 4.5 & 81 & 3.9 & 68 & 5.1 \\
\hline
\end{tabular}

summary of the treatment trains for each plant is shown in Additional file 6: Table S3. WWTP 1 served a largely urban population (approximately 500,000 people) with both domestic and industrial contribution. WWTP 2 served a considerably smaller population (approximately $17,000)$ with $73 \%$ of the population aged 65 or older (median age of 72 years). WWTP 3 has a capacity of approximately 70 million gallons per day (MGD) and has a predominantly domestic source of wastewater contribution. Thus, the three plants offered significantly different qualities of wastewater to be tested. DWTP 4 is an indirect potable reuse plant that receives treated wastewater effluent as its source water. The occurrence data for all $36 \mathrm{TOrCs}$ at different treatment points in the four plants is shown in Table 6 along with the sample volume extracted.

Sucralose (9000-32000 ng/L) and caffeine (6000$13280 \mathrm{ng} / \mathrm{L}$ ) were present at the highest concentration in the influent of all WWTPs. All pharmaceuticals analyzed in the influent of the three WWTPs were detected with the exception of diphenhydramine in WWTP 3. Concentrations of diabetes and heart-related pharmaceuticals like gemfibrozil, diclofenac, and primidone were significantly higher in the raw sewage of WWTP 2 (the plant serving the dominantly elderly community) compared to the other two WWTPs. Conversely, industrial compounds like benzophenone, PFOS, DEET, and bisphenol A were found at higher concentrations in WWTP 1 , potentially confirming the significant industrial input.

The mean effluent concentrations in all WWTPs of artificial sweetener sucralose $(13,860)$ and flame-retardant TCPP (2595 ng/L) were extremely high compared to the other analyzed TOrCs. Their concentrations remained fairly constant throughout the plant indicating that they may be robust and suitable markers for wastewater influence in drinking water sources. Six pharmaceuticals (carbamazepine, gemfibrozil, meprobamate, naproxen, primidone and sulfamethoxazole) were detected in the effluent of all WWTPs with mean concentrations between 85-755 ng/L. Average concentration of sulfamethoxazole (755 ng/L) and gemfibrozil $(634 \mathrm{ng} / \mathrm{L})$ were highest in the WWTP effluent for pharmaceuticals. The GR compounds were present at significantly lower concentrations in the influent and not detected in the final effluent in all three WWTPs. However, these compounds still need to be monitored closely as even trace amounts have been shown to have adverse effects to wildlife $[8,45]$. PFOS was the dominant PFC in terms of detection and concentration while the longer chain PFCs (PFDA and PFHxDA) were not detected at any point in all three WWTPs. PFBS was detected in the effluent of two WWTPs (1 and 2) but at concentration $<10 \mathrm{ng} / \mathrm{L}$ while PFBA was not detected in any of the effluent samples. Norgestrel was the more 
Table 6 Occurrence of TOrCs in different water matrices

\begin{tabular}{|c|c|c|c|c|c|c|c|c|c|c|}
\hline \multirow[t]{2}{*}{ Compound } & \multicolumn{3}{|c|}{ WWTP 1a } & \multicolumn{3}{|c|}{ WWTP 1b } & \multicolumn{4}{|c|}{ WWTP 2} \\
\hline & After GF & After AS & $\begin{array}{l}\text { Dechlorinated } \\
\text { final effluent }\end{array}$ & $\begin{array}{l}\text { After } \\
\text { AAS }\end{array}$ & $\begin{array}{c}\text { GMF } \\
\text { effluent }\end{array}$ & After UV & $\begin{array}{l}\text { After bar } \\
\text { screens }\end{array}$ & $\begin{array}{c}\text { After } \\
\text { BNROD }\end{array}$ & $\begin{array}{l}\text { After sand } \\
\text { filter }\end{array}$ & $\begin{array}{c}\text { After } \\
\text { chlorination }\end{array}$ \\
\hline Volume Extracted (ml) & 250 & 500 & 500 & 500 & 500 & 500 & 250 & 250 & 500 & 500 \\
\hline \multicolumn{11}{|l|}{ Pharmaceuticals } \\
\hline Carbamezapine & 260 & 230 & 230 & 270 & 270 & 260 & 580 & 470 & 460 & 400 \\
\hline Diclofenac & 96 & $<15$ & $<15$ & 78 & 34 & $<15$ & 830 & 530 & 420 & 14 \\
\hline Diltiazem & NA & NA & NA & NA & NA & NA & NA & NA & NA & NA \\
\hline Diphenhydramine & 1620 & 1480 & 1090 & 280 & 320 & 310 & 25 & 15 & 27 & $<7$ \\
\hline Fluoxetine & 160 & 32 & 57 & 41 & 44 & 24 & 79 & 38 & 23 & 34 \\
\hline Gemfibrozil & 2750 & 2380 & 2190 & 36 & 38 & 37 & $>6000$ & 400 & 230 & 190 \\
\hline Ibuprofen & $>6000$ & 1810 & 1590 & 41 & 41 & 52 & $>6000$ & 50 & $<50$ & $<30$ \\
\hline Meprobamate & 1600 & 650 & 480 & 680 & 670 & 610 & 597 & 421 & 570 & 190 \\
\hline Naproxen & $>6000$ & 550 & 300 & 11 & 10 & 4 & $>6000$ & 114 & 28 & 6 \\
\hline Primidone & 200 & 180 & 190 & 170 & 170 & 160 & 1120 & 620 & 580 & 580 \\
\hline Sulfamethoxazole & 2290 & 840 & 1130 & 1630 & 1510 & 990 & 6080 & 3910 & 3010 & 39 \\
\hline Trimethoprim & 1110 & 930 & 850 & 130 & 130 & 130 & 1370 & 30 & 12 & $<2$ \\
\hline \multicolumn{11}{|l|}{ Personal-care Products } \\
\hline Benzophenone & 6300 & 2320 & 1710 & 650 & 380 & 300 & 4540 & 310 & 310 & 220 \\
\hline Bisphenol A & 640 & 140 & 320 & $<90$ & $<80$ & $<40$ & 350 & 20 & 57 & 36 \\
\hline Caffeine & 12000 & 340 & 490 & 6 & 5 & 15 & 6000 & 22 & 10 & $<8$ \\
\hline DEET & 3570 & 540 & 630 & 46 & 45 & 44 & 2250 & 190 & 170 & 160 \\
\hline Sucralose & 32000 & 23000 & 15000 & 15600 & 14400 & 13500 & 9000 & 8170 & 7570 & 7950 \\
\hline TCEP & 780 & 690 & 650 & 380 & 350 & 330 & 550 & 330 & 320 & 260 \\
\hline TCPP & 1650 & 2900 & 3040 & 2970 & 2760 & 2380 & 5670 & 3870 & 3410 & 2910 \\
\hline Triclocarban & 330 & 31 & 42 & 62 & 96 & 38 & 740 & 200 & 68 & 110 \\
\hline Triclosan & 2250 & 440 & 162 & 85 & 71 & 28 & 4640 & 103 & 69 & 15 \\
\hline \multicolumn{11}{|c|}{ Perfluorinated compounds } \\
\hline PFBA & $<7$ & $<3$ & $<3$ & $<3$ & $<3$ & $<3$ & $<32$ & $<19$ & $<4$ & $<3$ \\
\hline PFBS & 17 & 10 & 9 & 13 & 14 & 10 & 24 & 9 & 8 & 5 \\
\hline PFOA & 9 & 7 & 9 & 11 & 45 & 24 & 0 & 46 & 49 & 60 \\
\hline PFOS & 1080 & 200 & 190 & 5 & 3 & 2 & 460 & 3 & 2 & 4 \\
\hline PFDA & $<13$ & $<8$ & $<7$ & $<7$ & $<7$ & $<6$ & $<11$ & $<10$ & $<10$ & $<5$ \\
\hline PFHxDA & $<3$ & $<2$ & $<2$ & $<2$ & $<2$ & $<2$ & $<6$ & $<4$ & $<4$ & $<1$ \\
\hline \multicolumn{11}{|l|}{ Glucocorticoid } \\
\hline Dexamethasone & 19 & $<14$ & $<10$ & $<22$ & $<14$ & $<10$ & 94 & $<77$ & $<26$ & $<18$ \\
\hline Hydrocortisone & $<20$ & $<12$ & $<11$ & $<48$ & $<11$ & $<11$ & NA & $<150$ & $<64$ & $<46$ \\
\hline Prednisone & $<165$ & $<61$ & 20 & $<61$ & $<59$ & $<28$ & 59 & NA & NA & NA \\
\hline Triamcinolone & $<55$ & $<23$ & $<21$ & $<27$ & $<21$ & $<21$ & 24 & $<14$ & $<12$ & $<7$ \\
\hline \multicolumn{11}{|l|}{ Pesticides } \\
\hline Atrazine & $<10$ & $<9$ & $<2$ & $<2$ & $<2$ & $<2$ & $<20$ & $<3$ & $<2$ & $<2$ \\
\hline Simazine & $<21$ & $<3$ & $<2$ & $<3$ & $<3$ & $<2$ & $<40$ & $<6$ & 4 & 3 \\
\hline \multicolumn{11}{|l|}{ Androgen } \\
\hline Testosterone & 14 & $<2$ & $<2$ & 15 & 14 & $<2$ & 15 & 4 & 3 & $<2$ \\
\hline \multicolumn{11}{|l|}{ Progestin } \\
\hline Norethistrone & $<19$ & $<16$ & $<5$ & $<5$ & $<4$ & $<2$ & 100 & 6 & $<5$ & $<5$ \\
\hline Norgestrel & 93 & 10 & 8 & 18 & 5 & 4 & 19 & 6 & 7 & 3 \\
\hline
\end{tabular}


Table 6 Occurrence of TOrCs in different water matrices (Continued)

\begin{tabular}{|c|c|c|c|c|c|c|c|c|c|c|c|}
\hline \multirow[t]{2}{*}{ Compound } & \multicolumn{4}{|c|}{ WWTP 3} & \multicolumn{4}{|c|}{ DWTP 4} & \multirow[b]{2}{*}{$\begin{array}{l}\text { Sacramento } \\
\text { River }\end{array}$} & \multirow[b]{2}{*}{$\begin{array}{c}\text { Colorado } \\
\text { River }\end{array}$} & \multirow[b]{2}{*}{$\begin{array}{c}\text { Tucson } \\
\text { GW }\end{array}$} \\
\hline & Influent & PostF/S & Post AS & $\begin{array}{l}\text { Dechlorinated } \\
\text { final effluent }\end{array}$ & Influent & $\begin{array}{c}\text { Post } \\
\text { MF }\end{array}$ & $\begin{array}{l}\text { Post } \\
\text { RO }\end{array}$ & $\begin{array}{l}\text { Post } \\
\text { UV }\end{array}$ & & & \\
\hline Volume Extracted (ml) & 250 & 250 & 250 & 500 & 250 & 500 & 1000 & 1000 & 1000 & 1000 & 1000 \\
\hline \multicolumn{12}{|l|}{ Pharmaceuticals } \\
\hline Carbamezapine & 1620 & 1760 & 580 & 590 & 180 & 190 & $<0.5$ & $<0.5$ & $<0.5$ & 1 & $<0.5$ \\
\hline Diclofenac & 340 & 370 & 280 & 260 & 120 & 70 & $<8$ & $<8$ & $<8$ & $<8$ & $<8$ \\
\hline Diltiazem & 280 & 280 & 130 & 59 & 240 & 140 & 75 & 73 & $<2$ & $<2$ & $<2$ \\
\hline Diphenhydramine & $<73$ & $<19$ & $<9$ & $<5$ & 470 & 420 & $<1$ & $<1$ & $<1$ & $<1$ & $<1$ \\
\hline Fluoxetine & 88 & 110 & 89 & 84 & $<9$ & $<7$ & $<1$ & $<1$ & $<1$ & $<1$ & $<1$ \\
\hline Gemfibrozil & 5550 & 5300 & 75 & 120 & 680 & 540 & $<1$ & $<1$ & $<1$ & $<1$ & $<1$ \\
\hline Ibuprofen & 3780 & 3410 & $<15$ & $<15$ & 180 & 120 & $<15$ & $<15$ & $<15$ & $<15$ & $<15$ \\
\hline Meprobamate & 690 & 540 & 340 & 280 & 375 & 360 & $<3$ & $<3$ & $<3$ & 3 & $<3$ \\
\hline Naproxen & 4740 & 4170 & 24 & 30 & 970 & 460 & $<3$ & $<3$ & $<3$ & $<3$ & $<3$ \\
\hline Primidone & 370 & 370 & 300 & 300 & $<20$ & $<8$ & $<4$ & $<4$ & $<4$ & $<4$ & $<3$ \\
\hline Sulfamethoxazole & 4040 & 3280 & 1640 & 860 & 590 & 590 & 1 & 1 & 1 & 5 & $<1$ \\
\hline Trimethoprim & 1510 & 1420 & 280 & 200 & 830 & 810 & $<0.5$ & $<0.5$ & $<0.5$ & 1 & $<0.5$ \\
\hline \multicolumn{12}{|l|}{ Personal-care Products } \\
\hline Benzophenone & 1670 & 1640 & 340 & 250 & 880 & 280 & 150 & 130 & 114 & 15 & 21 \\
\hline Bisphenol A & 240 & 240 & 30 & $<25$ & 69 & $<20$ & $<20$ & $<20$ & $<20$ & $<20$ & $<20$ \\
\hline Caffeine & 13680 & 11320 & 12 & 12 & 11 & 10 & $<3$ & $<3$ & 4 & 14 & $<3$ \\
\hline DEET & 700 & 350 & 110 & 130 & 93 & 220 & $<3$ & $<3$ & 5 & 5 & 3 \\
\hline Sucralose & 23000 & 21000 & 19000 & 19000 & 25000 & 23000 & 38 & 34 & 47 & 620 & $<31$ \\
\hline TCEP & 630 & 460 & 400 & 370 & & & $<3$ & $<3$ & $<3$ & $<3$ & $<3$ \\
\hline TCPP & 2000 & 2040 & 2080 & 2050 & 730 & 1060 & $<3$ & $<3$ & 11 & 9 & 3 \\
\hline Triclocarban & 580 & 520 & 120 & 9 & 50 & 87 & $<2$ & $<2$ & $<2$ & $<2$ & $<2$ \\
\hline Triclosan & 1790 & 2000 & 52 & 29 & $<39$ & $<13$ & $<6$ & $<6$ & $<6$ & $<6$ & $<6$ \\
\hline \multicolumn{12}{|c|}{ Perfluorinated compounds } \\
\hline PFBA & NA & NA & NA & NA & 10 & 9 & 7 & $<3$ & $<3$ & $<3$ & $<3$ \\
\hline PFBS & $<5$ & $<4$ & $<3$ & $<3$ & $<3$ & $<2$ & $<1$ & $<1$ & $<1$ & $<1$ & $<1$ \\
\hline PFOA & $<40$ & $<31$ & $<21$ & $<10$ & $<4$ & $<2$ & $<1$ & $<1$ & $<1$ & $<1$ & $<1$ \\
\hline PFOS & 16 & 9 & 10 & 9 & 530 & 290 & 200 & $<1$ & $<1$ & $<1$ & $<1$ \\
\hline PFDA & $<12$ & $<10$ & $<10$ & $<10$ & $<12$ & $<6$ & $<3$ & $<3$ & $<3$ & $<3$ & $<3$ \\
\hline PFHXDA & $<11$ & $<10$ & $<9$ & $<9$ & $<3$ & $<2$ & $<1$ & $<1$ & $<1$ & $<1$ & $<1$ \\
\hline \multicolumn{12}{|l|}{ Glucocorticoid } \\
\hline Dexamethasone & $<61$ & $<11$ & $<7$ & $<6$ & $<44$ & $<20$ & $<1$ & $<1$ & $<1$ & $<1$ & $<1$ \\
\hline Hydrocortisone & $<17$ & $<15$ & $<7$ & $<5$ & $<90$ & $<50$ & $<4$ & $<4$ & $<4$ & 7 & $<5$ \\
\hline Prednisone & NA & $<30$ & $<25$ & $<25$ & $<700$ & $<200$ & $<25$ & $<25$ & $<25$ & $<25$ & $<25$ \\
\hline Triamcinolone & $<61$ & $<54$ & $<26$ & $<12$ & $<200$ & $<80$ & $<7$ & $<7$ & $<7$ & $<7$ & $<6$ \\
\hline \multicolumn{12}{|l|}{ Pesticides } \\
\hline Atrazine & $<3$ & $<2$ & $<2$ & $<1$ & $<19$ & $<6$ & $<1$ & $<1$ & $<1$ & $<1$ & $<1$ \\
\hline Simazine & $<6$ & $<4$ & $<2$ & $<2$ & $<38$ & $<12$ & $<2$ & $<2$ & $<2$ & 2 & $<2$ \\
\hline \multicolumn{12}{|l|}{ Androgen } \\
\hline Testosterone & $<11$ & $<8$ & $<5$ & $<2$ & 9 & 9 & $<1$ & $<1$ & $<1$ & $<2$ & $<1$ \\
\hline \multicolumn{12}{|l|}{ Progestin } \\
\hline Norethistrone & $<30$ & $<7$ & $<3$ & $<2$ & $<18$ & $<7$ & $<3$ & $<3$ & $<3$ & $<3$ & $<3$ \\
\hline Norgestrel & 620 & 230 & $<3$ & $<2$ & 110 & 110 & $<4$ & $<4$ & $<3$ & $<3$ & $<3$ \\
\hline
\end{tabular}

Attached excel file to be placed in main text.

NA Not analyzed. 
frequently detected progestin, present in two effluent WWTP samples (WWTP 1 and 2), while norethisterone was never detected in the effluent. The pesticide atrazine was not detected in any of the samples analyzed throughout the study.

To study the treatment efficacy of the WWTPs, samples were collected at different points in the plant. Further, WWTP 1 had water split into two parallel trains after primary treatment: conventional (activated sludge followed by chlorination) and advanced (advanced air activated sludge, granular media filtration and UV disinfection). The biggest factor in removal of TOrCs between the two treatment trains in WWTP 1 was the type of activated sludge (AS) used. The advanced air activated sludge (AAS) process provided significantly lower concentration of most TOrCs as compared to the AS effluent in the conventional train. The sand filter in WWTP 2 did not have much attenuation of TOrCs, similar to previous literature [46]. Compounds like diclofenac, sulfamethoxazole, naproxen, and triclosan were well removed by the free chlorine disinfection step which is consistent with previously published literature [6]. Conversely, compounds such as DEET, TCPP, TCEP and caffeine are known to be recalcitrant at chlorine doses supplied in conventional treatment plants and hence were not well removed in the chlorination step in both treatment plants. The UV disinfection process (in WWTP 1b) was not very effective in attenuation of TOrCs without the addition of hydrogen peroxide. In DWTP 4, very few TOrCs were attenuated by microfiltration process, which is consistant with previous literature [47]. However, almost no traces of any TOrCs were detected after the reverse osmosis (RO) process. Only six (benzophenone, diltiazem, PFBA, PFOS, sucralose and sulfamethoxazole) of the 36 measured TOrCs were present after RO treatment in DWTP 4. Of these six, only benzophenone and PFOS were present at concentrations $>100 \mathrm{ng} / \mathrm{L}$.

Two surface waters from the Colorado River (sampled at Avra Valley, AZ through the CAP canal) and Sacramento River were analyzed using this method. Eleven target compounds were detected in the Colorado River water while seven were seen in the Sacramento River sample. Six of the target analytes (sucralose, meprobamate, caffeine, DEET, TCPP and benzophenone) were common to both waters. Sucralose was present at the highest concentration in the Colorado River samples at $620 \mathrm{ng} / \mathrm{L}$ while in the Sacramento River sample it was measured at $47 \mathrm{ng} / \mathrm{L}$. Commercially used compounds like benzophenone and TCPP were detected at higher concentrations in the Sacramento river while all the other analytes detected were higher in the Colorado River sample. The groundwater sample collected from Tucson had trace amounts of DEET and TCPP $(<5 \mathrm{ng} / \mathrm{L})$, and benzophenone at $21 \mathrm{ng} / \mathrm{L}$ but all other
TOrCs were not detected. Although the sampling events were limited, the data generally correlate with previous studies and hence prove the viability of the analytical method.

\section{Conclusion}

The analytical method presented above allows for rapid, high-throughput detection and quantitation of up to 36 TOrCs including pharmaceuticals, personal care products and steroid hormones using UHPLC-MS/MS. The use of a single all-inclusive SPE method coupled to UHPLC MS/MS provides significant time and labor savings while achieving reporting limits of low $\mathrm{ng} / \mathrm{L}$ for all analytes. The method has been applied to a wide-range of aqueous matrices. The authors suggest using routine blank analysis, matrix spike recoveries and isotopicallylabeled standards for obtaining most accurate results when analyzing different water matrixes.

\section{Additional files}

\section{Additional file 1: Table S1. UPLC MS/MS target analytes with mass transitions, compound specific parameters and isotopically labeled surrogate used for quantification. \\ Additional file 2: Table S2. Specifications of UHPLC reverse phase analytical columns tested.}

Additional file 3: Figure S1. Overlaid EIC traces of the most abundant transition in ESI positive of a methanol blank. The peak at $5.6 \mathrm{~min}$ is DEET.

Additional file 4: Figure S2. Overlaid EIC traces of the most abundant transition in ESI negative of a methanol blank.

Additional file 5: Figure S3. Overlaid EIC of the most abundant transition of DEET in a methanol blank and fortified methanol blank.

Additional file 6: Table S3. Summary of treatment processes employed at the three treatment plants included in this study.

\section{Abbreviations}

CAV: Cell accelerator voltage; CE: Collision energy; DEET: N,N-Diethyl-metatoluamide; DWTP: Drinking water treatment plant; ESI: Electrospray ionization; GC: Gas chromatography; GRs: Glucocorticoids; LC: Liquid chromatography; LOD: Limit of detection; LOQ: Limit of quantification; MRL: Method reporting limit; MS: Mass spectrometry; PFBA: Perfluoro butyric acid; PFBS: Perfluoro butane sulfonate; PFC: Polyfluorinated chemical; PFDA: Perfluoro decanoic acid; PFHxDA: Perfluoro hexadecanoic acid; PFOA: Perfluoro octanoic acid; PFOS: Perfluoro octane sulfonate; RO: Reverse osmosis; SPE: Solid-phase extraction; TCEP: Tris (2-chloroethyl) phosphate; TCPP: Tris (2-chloropropyl) phosphate; TOrC: Trace organic contaminant.

\section{Competing interests}

The authors declare that they have no competing interest.

\section{Authors' contributions}

TA was the primary contributor to this manuscript. TA was responsible for preparing the first draft of the manuscript and performed most of the experimentation and analysis while also being involved heavily in data acquisition and interpretation. SM was involved in design of the experiments and performing some of the data acquisition and analysis. SM also provided critical advice on operation of the analytical equipment due to previous expertise. BOC was involved in conceptualization of the project and did a lot of the initial analytical work. BOC also had a significant role in development of the experiments and interpretation of results. SAS made a considerable intellectual contribution to the development of the study and was chiefly responsible for designing the framework for all the experiments. SAS also 
had a huge role in producing the finished manuscript and was solely responsible for acquiring funding to purchase all the analytical equipment used in this study. All authors read and approved the final manuscript.

\section{Acknowledgements}

The authors would like to thank the participating utilities particularly Chris Hill from Metro Water for technical assistance in sample collection and transport. We also thank Dr. Armando Durazo, Shimin Wu and Massimiliano Sgroi from the University of Arizona for assistance with solid-phase extraction and sample preparation. The authors are also grateful to Agilent Technologies for providing technical support during method development.

\section{Author details}

${ }^{1}$ Department of Chemical \& Environmental Engineering, University of Arizona, 1133 E James E Rogers Way, Harshbarger 108, Tucson, AZ 85721-0011, USA. ${ }^{2}$ School of Applied Sciences, RMIT University, 100 LaTrobe St, Melbourne 3000, Australia.

Received: 9 April 2013 Accepted: 27 May 2013

Published: 18 June 2013

\section{References}

1. Kolpin DW, Furlong ET, Meyer MT, Thurman EM, Zaugg SD, Barber LB, Buxton HT: Pharmaceuticals, hormones, and other organic wastewater contaminants in US streams, 1999-2000: a national reconnaissance. Environ Sci Technol 2002, 36(6):1202-1211.

2. Snyder SA, Westerhoff P, Yoon Y, Sedlak DL: Pharmaceuticals, personal care products, and endocrine disruptors in water: implications for the water industry. Environ Eng Sci 2003, 20(5):449-469.

3. Focazio MJ, Kolpin DW, Barnes KK, Furlong ET, Meyer MT, Zaugg SD, Barber LB, Thurman ME: A national reconnaissance for pharmaceuticals and other organic wastewater contaminants in the United States - II) Untreated drinking water sources. Sci Total Environ 2008, 402(2-3):201-216.

4. Benotti MJ, Trenholm RA, Vanderford BJ, Holady JC, Stanford BD, Snyder SA: Pharmaceuticals and endocrine disrupting compounds in US drinking water. Environ Sci Technol 2009, 43(3):597-603.

5. Snyder S, Westerhoff P, Yoon Y, Vanderford B, Rexing D: Evaluation of conventional and advanced treatment processes to remove endocrine disruptors and pharmaceutically active compounds. Abstr Pap Am Chem Soc 2004, 228:184. ENVR.

6. Westerhoff $P$, Yoon $Y$, Snyder S, Wert E: Fate of endocrine-disruptor, pharmaceutical, and personal care product chemicals during simulated drinking water treatment processes. Environ Sci Technol 2005, 39(17):6649-6663.

7. Snyder SA, Wert EC, Lei H, Westerhoff P, Yoon Y: Removal of EDCs and Pharmaceuticals in Drinking and Reuse Treatment Processes. Denver, CO: American Water Works Association Research Foundation; 2007.

8. Bevans HE, Goodbred SL, Miesner JF, Watkins SA, Gross TS, Denslow ND, Trenton C: Synthetic organic compounds and carp endocrinology and histology, Las Vegas Wash and Las Vegas and Callville Bays of Lake Mead Nevada, 1992 and 1995: U.S. Geological Survey Water-Resources Investigations Report; 1995:96-4266. 12 accessible at: http://pubs.er.usgs.gov/publication/ wri964266.

9. Daughton CG, Ternes TA: Pharmaceuticals and personal care products in the environment: agents of subtle change? Environ Health Perspect 1999, 107:907-938.

10. Carlsson C, Johansson AK, Alvan G, Bergman K, Kuhler T: Are pharmaceuticals potent environmental pollutants? Part I: environmental risk assessments of selected active pharmaceutical ingredients. Sci Total Environ 2006, 364(1-3):67-87.

11. Snyder SA, Villeneuve DL, Snyder EM, Giesy JP: Identification and quantification of estrogen receptor agonists in wastewater effluents. Environ Sci Technol 2001, 35(18):3620-3625.

12. Stanford BD, Snyder SA, Trenholm RA, Holady JC, Vanderford BJ: Estrogenic activity of US drinking waters: a relative exposure comparison. J Am Water Work Assoc 2010, 102(11):55-65.

13. Ryu J, Yoon Y, Oh J: Occurrence of endocrine disrupting compounds and pharmaceuticals in 11 WWTPs in Seoul, Korea. KSCE J Civ Eng 2011, 15(1):57-64.
14. Chang H, Hu JY, Shao B: Occurrence of natural and synthetic glucocorticoids in sewage treatment plants and receiving river waters. Environ Sci Technol 2007, 41(10):3462-3468.

15. Herrero P, Borrull F, Pocurull E, Marce RM: Determination of glucocorticoids in sewage and river waters by ultra-high performance liquid chromatography-tandem mass spectrometry. J Chromatogr A 2012, 1224:19-26

16. Schriks M, van Leerdam JA, van der Linden SC, van der Burg B, van Wezel $A P$, de Voogt $P$ : High-resolution mass spectrometric identification and quantification of glucocorticoid compounds in various wastewaters in the Netherlands. Environ Sci Technol 2010, 44(12):4766-4774.

17. Quinones O, Snyder SA: Occurrence of perfluoroalkyl carboxylates and sulfonates in drinking water utilities and related waters from the United States. Environ Sci Technol 2009, 43(24):9089-9095.

18. Mak YL, Taniyasu S, Yeung LWY, Lu GH, Jin L, Yang YL, Lam PKS, Kannan K, Yamashita N: Perfluorinated compounds in tap water from China and several other countries. Environ Sci Technol 2009, 43(13):4824-4829.

19. Clarke BO, Smith SR: Review of 'emerging' organic contaminants in biosolids and assessment of international research priorities for the agricultural use of biosolids. Environ Int 2011, 37(1):226-247.

20. Zhang T, Wu Q, Sun HW, Zhang XZ, Yun SH, Kannan K: Perfluorinated compounds in whole blood samples from infants, children, and adults in China. Environ Sci Technol 2010, 44(11):4341-4347.

21. Contaminant Candidate List 3. http://water.epa.gov/scitech/drinkingwater/ $\mathrm{dws} / \mathrm{ccl} / \mathrm{ccl} 3 . \mathrm{cfm}$.

22. Lau C, Butenhoff $J$, Rogers JM: The developmental toxicity of perfluoroalkyl acids and their derivatives. Toxicol Appl Pharmacol 2004, 198(2):231-241.

23. Lau C, Anitole K, Hodes C, Lai D, Pfahles-Hutchens A, Seed J: Perfluoroalkyl acids: a review of monitoring and toxicological findings. Toxicol Sci 2007 99(2):366-394

24. Directive 2006/122/EC of the European Parliament and of the council of 12 December 2006. http://eur-lex.europa.eu/LexUriServ/LexUriServ.do?uri=OJ: L:2006:372:0032:0034:en:PDF.

25. Wilhelm M, Bergmann S, Dieter $\mathrm{HH}$ : Occurrence of perfluorinated compounds (PFCs) in drinking water of North Rhine-Westphalia, Germany and new approach to assess drinking water contamination by shorter-chained C4-C7 PFCs. Int J Hyg Environ Health 2010, 213(3):224-232.

26. Hinton TG, Aizawa K: A Layperson's Primer on Multiple Stressors, Chapter 5. In Multiple Stressors: A Challenge for the Future; 2007:57-69.

27. Dickenson ERV, Snyder SA, Sedlak DL, Drewes JE: Indicator compounds for assessment of wastewater effluent contributions to flow and water quality. Water Res 2011, 45(3):1199-1212.

28. Ternes TA: Analytical methods for the determination of pharmaceuticals in aqueous environmental samples. Trac-Trends Anal Chem 2001, 20(8):419-434

29. Trenholm RA, Vanderford BJ, Drewes JE, Snyder SA: Determination of household chemicals using gas chromatography and liquid chromatography with tandem mass spectrometry. J Chromatogr A 2008, 1190(1-2):253-262.

30. Stafiej A, Pyrzynska K, Regan F: Determination of anti-inflammatory drugs and estrogens in water by HPLC with UV detection. J Sep Sci 2007, 30(7):985-991.

31. Morishima Y, Hirata Y, Jinno K, Fujimoto C: Solid-phase extraction device coupled to a microcolumn liquid chromatograph with a UV detector for determining estrogens in water samples. J Liq Chromatogr Relat Technol 2005, 28(20):3217-3228.

32. Zotou A, Miltiadou N: Sensitive LC determination of ciprofloxacin in pharmaceutical preparations and biological fluids with fluorescence detection. J Pharm Biomed Anal 2002, 28(3-4):559-568.

33. Zotou A, Vasiliadou C: A fluorescence-LC method for the determination of sulfonamides in biological fluids with pre-column derivatization. Chromatographia 2009, 70(3-4):389-397.

34. Lindsey ME, Meyer M, Thurman EM: Analysis of trace levels of sulfonamide and tetracycline antimicrobials, in groundwater and surface water using solid-phase extraction and liquid chromatography/mass spectrometry. Anal Chem 2001, 73(19):4640-4646.

35. La Farre M, Ferrer I, Ginebreda A, Figueras M, Olivella L, Tirapu L, Vilanova M, Barcelo D: Determination of drugs in surface water and wastewater samples by liquid chromatography-mass spectrometry: methods and preliminary results including toxicity studies with Vibrio fischeri. J Chromatogr A 2001, 938(1-2):187-197. 
36. Bossi R, Vejrup KV, Mogensen BB, Asman WAH: Analysis of polar pesticides in rainwater in Denmark by liquid chromatography-tandem mass spectrometry. J Chromatogr A 2002, 957(1):27-36.

37. Gros M, Petrovic M, Barcelo D: Development of a multi-residue analytical methodology based on liquid chromatography-tandem mass spectrometry (LC-MS/MS) for screening and trace level determination of pharmaceuticals in surface and wastewaters. Talanta 2006, 70(4):678-690.

38. Ternes $T$, Bonerz $M$, Schmidt $T$ : Determination of neutral pharmaceuticals in wastewater and rivers by liquid chromatography-electrospray tandem mass spectrometry. J Chromatogr A 2001, 938(1-2):175-185.

39. Tong $L$, Li P, Wang YX, Zhu KZ: Analysis of veterinary antibiotic residues in swine wastewater and environmental water samples using optimized SPE-LC/MS/MS. Chemosphere 2009, 74(8):1090-1097.

40. Vanderford BJ, Pearson RA, Rexing DJ, Snyder SA: Analysis of endocrine disruptors, pharmaceuticals, and personal care products in water using liquid chromatography/tandem mass spectrometry. Anal Chem 2003, 75(22):6265-6274.

41. Trenholm RA, Vanderford BJ, Holady JC, Rexing DJ, Snyder SA: Broad range analysis of endocrine disruptors and pharmaceuticals using gas chromatography and liquid chromatography tandem mass spectrometry. Chemosphere 2006, 65(11):1990-1998.

42. Vanderford BJ, Mawhinney DB, Trenholm RA, Zeigler-Holady JC, Snyder SA: Assessment of sample preservation techniques for pharmaceuticals, personal care products, and steroids in surface and drinking water. Anal Bioanal Chem 2011, 399(6):2227-2234.

43. Maldaner $L$, Jardim I: Determination of some organic contaminants in water samples by solid-phase extraction and liquid chromatography tandem mass spectrometry. Talanta 2012, 100:38-44.

44. Aboulfadl K, De Potter C, Prevost M, Sauve S: Time-dependent integrity during storage of natural surface water samples for the trace analysis of pharmaceutical products, feminizing hormones and pesticides. Chem Cent J 2010, 4(1):10.

45. Sanderson H, Johnson DJ, Reitsma T, Brain RA, Wilson CJ, Solomon KR: Ranking and prioritization of environmental risks of pharmaceuticals in surface waters. Regul Toxicol Pharmacol 2004, 39(2):158-183.

46. Boleda MR, Galceran MT, Ventura F: Behavior of pharmaceuticals and drugs of abuse in a drinking water treatment plant (DWTP) using combined conventional and ultrafiltration and reverse osmosis (UF/RO) treatments. Environ Pollut 2011, 159(6):1584-1591.

47. Snyder SA, Adham S, Redding AM, Cannon FS, DeCarolis J, Oppenheimer J Wert EC, Yoon Y: Role of membranes and activated carbon in the removal of endocrine disruptors and pharmaceuticals. Desalination 2007, 202(1-3):156-181.

doi:10.1186/1752-153X-7-104

Cite this article as: Anumol et al:: Ultra high performance liquid

chromatography tandem mass spectrometry for rapid analysis of trace organic contaminants in water. Chemistry Central Journal 2013 7:104.



